\title{
Analysis of Impact and Tensile Properties of Recycled Polypropylene
}

\author{
Luiz Gustavo Barbosa*, Matheus Piaia, Gustavo Henrique Ceni
}

Instituto Federal de Educação, Ciência e Tecnologia do Rio Grande do Sul - Campus Erechim, Erechim, Brazil

\begin{abstract}
The present research proposed to evaluate the tensile and impact properties of polypropylene originating from secondary recycling. The polymer chosen for the studies was polypropylene (PP) for its high application and availability. The tensile and impact tests were performed on virgin polypropylene, recycled polypropylene and mixtures of different proportions of both. Thus, for each sample, values of yield strength, elastic modulus, yield elongation and impact strength were obtained. The results of the averages obtained demonstrated that the tensile properties of virgin PP and recycled PP are similar, as well as those of the mixtures between both. Regarding the impact properties, it was observed that the energy absorbed by the recycled polymers is lower than that of the virgin polypropylene. Consequently, recycled polypropylene can replace virgin polypropylene in applications which are subjected to tension stress but not in those subjected it to impact.
\end{abstract}

Keywords Polymers, Recycled Polypropylene, Tensile Properties, Impact Properties

\section{Introduction}

Nowadays, all action related to the disposal of any material should be considered based on the strategy of the four R's: reduction (combating waste generation), reuse (of materials), recycle (use of discarded material in new products) and recover (energy extraction from discarded waste) [1, 2]. Plastic recycling programs have been boosted in the last decade due to growing concern about the environment, the lack of space for the construction of landfills, and even the pressure not only from legislation but also from the society about this disposal [3], since these materials take thousands of years to spontaneously degradate [4]. Beyond keeping the planet clean, recycling offers the potential to reduce fossil fuel consumption, since recycled plastic can compete directly with virgin plastic produced from refined fossil fuels, and the electrical energy needed to process recycled plastics is notably lower than for virgin material [5].

The main application of PP is in the food sector, representing $32 \%$ in products such as: packaging, lids, tupperwares, jars, bottles and gallons. In the consumer goods sector PP represents $17 \%$ of the market and is applied in packaging and boxes. In civil construction represents 3\% of the market and, among others, it replaces asbestos in fibre cement tiles and water tanks, and it serves as a partial substitute of concrete in slabs with the use of BubbleDeck.

* Corresponding author:

luiz.barbosa@erechim.ifrs.edu.br (Luiz Gustavo Barbosa)

Published online at http://journal.sapub.org/ijme

Copyright (C) 2017 Scientific \& Academic Publishing. All Rights Reserved
Also, it is a raw material for the Pack Less, a plastic pallet. In the automotive sector it represents $9 \%$ of the market, being used in dashboards, door panels, bumpers, grilles, for example. [6]. Therefore, all this material when discarded can be recycled and originate new products. In Brazil, about $8.2 \%$ of the post-consumer polypropylene is recycled, which is processed into pellets through mechanical recycling and subsequently produces packaging, automobile components and other recycled products [7].

However, few studies have been to verify if the properties of the recycled polymers are similar to those of the virgin polymers. Fernandes and Domingues [8] compared the mechanical properties between virgin high impact polypropylene, injected, and the recycled one. With the purpose of applying the recycled polypropylene in the automotive industry, two mixtures were tested, one composed of $30 \%$ recycled $\mathrm{PP}$ and $70 \%$ virgin $\mathrm{PP}$, and other one of $50 \%$ recycled PP and 50\% virgin PP. They observed that the mechanical properties under tensile strength (ultimate tensile strength, yield strength and strain) did not vary, however, the impact resistance only for samples with up to $30 \%$ recycled PP was acceptable for automotive use. Samples above this percentage $(50 \%$ and $100 \%$ recycled PP) showed a large reduction in impact strength. For comparative purposes the virgin PP had an impact resistance of $78,7 \mathrm{~kJ} / \mathrm{m}^{2}$ and the PP $100 \%$ recycled $19,7 \mathrm{~kJ} / \mathrm{m}^{2}$.

Likewise, Raj et al [9] tested the tensile and impact mixtures of injected virgin and recycled polypropylene in different proportions and have not obtained significant variation in yield strength and elastic modulus. However for the impact resistance, as the percentage of recycled PP 
increased, such property decreased, having a value of 55,9 $\mathrm{kJ} / \mathrm{m}^{2}$ for the $100 \%$ virgin PP and $45,3 \mathrm{~kJ} / \mathrm{m}^{2}$ for the mixture of $60 \%$ virgin $\mathrm{PP}$ and $40 \%$ recycled PP.

Such decrease in some properties can be justified in many cases by the uncertainty of the composition of the samples, since the raw material comes from secondary recycling, having artifacts discarded from different materials [10]. Still the loss of impact property can occur due to the reduction of the molecular weight that the recycling promotes. Such reduction increases the mobility of the chains, allowing the formation of thinner lamellae and a higher degree of crystallization. Furthermore, the degradation suffered by the polypropylene material leads to a shearing of the main chain and consequently reduces the viscosity, directly affecting its mechanical properties [4]. However, all the previous works demonstrate that for certain percentages of recycled PP in a mixture with virgin PP the mechanical properties generally suffer few reductions, reinforcing the technical and economic viability of the recycling.

Therefore, the present work tested if the tensile and impact properties of recycled polypropylene are the same of virgin polypropylene. Such recycled PP is used by Cavaletti S.A, leading office chair manufacturer in the Brazilian market.

\section{Materials and Methods}

Virgin polypropylene (PPv) type CP442XP produced by the company Braskem S.A. with yield strength of $24 \mathrm{MPa}$ and polypropylene from secondary recycling ( $\mathrm{PPr}$ ) supplied by the company Coplast were used. The materials were blended in the proportions shown in Table 1.

Table 1. Composition of the Samples Used in the Tests

\begin{tabular}{ccc}
\hline \multirow{2}{*}{ Sample } & \multicolumn{2}{c}{ Composition } \\
\cline { 2 - 3 } & Virgin (\%) & Recycled (\%) \\
\hline PPv100 & 100 & - \\
PPr10 & 90 & 10 \\
PPr20 & 80 & 20 \\
PPr30 & 70 & 30 \\
PPr100 & - & 100 \\
\hline
\end{tabular}

The specimens for the tensile and impact tests were injected by Cavaletti S.A., located in the city of Erechim Brazil, following the dimensional requirements of ASTM D638-02a and ASTM D256-02, respectively. Table 2 shows the parameters used during their injection.

Using the specimens injected, tensile tests were performed according to ASTM D638-02a, operating at a speed of $5 \mathrm{~mm}$ / min and at room temperature. Five specimens of each mixture were tested and then the mean values of elastic modulus, yield strength and yield strain were obtained. To perform the tensile tests a universal testing machine model WDWV100E, made by Time Group was used, located in the test laboratory of the IFRS - Erechim Campus, controlled by WinWDW software, and has a $100 \mathrm{kN}$ load cell and a strain gauge.

Table 2. Injection Parameters Used in the Preparations of Test Specimens

\begin{tabular}{lc}
\hline \multicolumn{1}{c}{ Injection Parameter } & Value \\
\hline Maximum holding pressure $(\mathrm{MPa})$ & 35 \\
Maximum injection pressure $(\mathrm{MPa})$ & 50 \\
Maximum back pressure $(\mathrm{MPa})$ & 8 \\
Decompression pressure $(\mathrm{MPa})$ & 55 \\
Injection time (s) & 5 \\
Temperature of zones 1 to $4\left({ }^{\circ} \mathrm{C}\right)$ & 200 \\
Temperature of zone $5($ injection$)\left({ }^{\circ} \mathrm{C}\right)$ & 195 \\
\hline
\end{tabular}

Impact tests were performed according to ASTM D256-02 in a controlled environment, with a room temperature of $23 \pm$ $2^{\circ} \mathrm{C}$ and a relative humidity of $50 \pm 10 \%$. The impact strength value was obtained by the ratio of the average energy absorbed by 8 specimens tested according to the dimensions specified in the standard. The tests were performed with a Zwick Izod impact testing machine, located at the IFRS - Farroupilha Campus. The hammer used for the test provides $4.0 \mathrm{~J}$ of energy and was released from a height of $610 \mathrm{~mm}$ in relation to base.

\section{Results and Discussions}

From the values collected from the software WinWDW, which controls the universal testing machine, the graphs of Figure 1 were obtained. The stress-strain curves for the PPv100, PPr10, PPr20, PPr30 and PPr100 samples are shown in it.

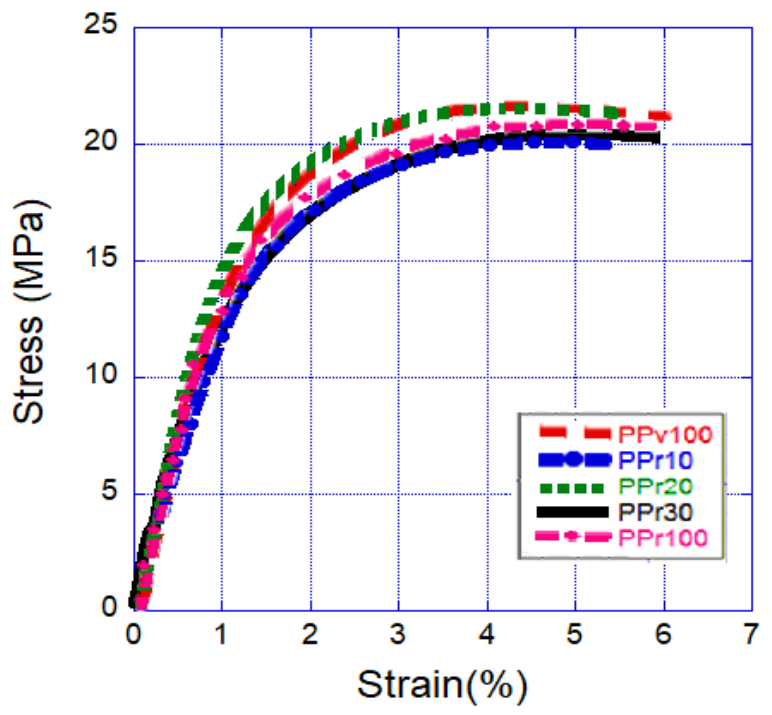

Figure 1. Stress Versus Strain Comportment of PPv100, PPr10, PPr20, PPr30 and PPr100 Samples

From these graphs, the mean values of the yield strength $(\sigma e)$, the elastic modulus (E) and the respective standard deviations were obtained, as shown in Table 3. 
Table 3. Mean and Standard Deviation of Yield Strength ( $\sigma e)$ and Elastic Modulus (E) for PPv100, PPr10, PPr20, PPr30 e PPr100 Samples

\begin{tabular}{ccc}
\hline Sample & $\boldsymbol{\sigma}_{\mathbf{e}}(\mathbf{M P a})$ & $\mathbf{E}$ (MPa) \\
\hline PPv100 & $21,65 \pm 0,38$ & $1761,11 \pm 51,25$ \\
$\operatorname{PPr} 10$ & $20,96 \pm 0,62$ & $1742,24 \pm 98,17$ \\
$\operatorname{PPr} 20$ & $21,53 \pm 0,50$ & $1758,94 \pm 228,40$ \\
$\operatorname{PPr} 0$ & $20,46 \pm 0,47$ & $1702,69 \pm 16,21$ \\
PPr100 & $20,83 \pm 0,03$ & $1760,31 \pm 23,62$ \\
\hline
\end{tabular}

It is noted that, in general, the yield stress has little changes with the addition of recycled PP in the blend with the virgin PP. In a direct comparison between the extremes, PPv100 and PPr100, there is a change in the value of only $3.87 \%$ for such property. The same occurs for the elastic modulus, where occurred a modification of less than $1 \%$. However, the elastic modulus for the $20 \%$ recycled sample had a high standard deviation, which can be due to the difficulty of using the strain gauge available for the tests.

Table 4 shows the mean values of the impact resistance values on the same samples.

Table 4. Mean and Standard Deviation of Impact Resistance for PPv100, PPr10, PPr20, PPr30 and PPr100 Samples

\begin{tabular}{cc}
\hline Sample & Impact Resistance $\left(\mathbf{k J} / \mathbf{m}^{2}\right)$ \\
\hline PPv100 & $49,53 \pm 3,49$ \\
PPr10 & $28,58 \pm 11,75$ \\
PPr20 & $16,51 \pm 3,49$ \\
PPr30 & $13,34 \pm 2,22$ \\
PPr100 & $6,67 \pm 1,91$ \\
\hline
\end{tabular}

Nevertheless, the impact resistance gradually decreased with the increase of the recycled polypropylene concentration in the mixture, so that the impact resistance for PPr100 is 86\% lower than for PPv100, being $49.53 \mathrm{~kJ} / \mathrm{m}^{2}$ for the virgin and $6.67 \mathrm{~kJ} / \mathrm{m}^{2}$ for recycling.

Although, as only mechanical properties were analyzed, it is not possible to conclude the reason for the drop in impact strength while increasing the percentage of recycled polypropylene in the blend. However, as the material undergoes degradation during recycling as it is exposed to high temperatures and shear rates, which may be an explanation for the drop in the values of impact resistance [11-13].

\section{Conclusions}

Analysing the results obtained, it can be concluded that the properties under tensile stress (yield strength and elastic modulus) are little affected by the usage of either $100 \%$ recycled polymer or its mixture with virgin polymer. However, recycling causes PP embrittlement, which is confirmed by the reduction in impact strength. Such results are in agreement with those obtained by Fernandes and Domingues [8] and Raj et.al. [9], which also obtained constancy for the yield strength and elastic modulus and a decrease in impact strength as the percentage of recycled PP in the blend with virgin PP increased.

Therefore, the PP obtained by disposable and potentially recyclable objects, that is, PPr100, can be applied in situations that require tensile resistance without impact susceptibility. The low cost, when compared to the virgin, promotes competitive advantage for the plastic artifacts industries, which, by using recyclable materials, are contributing to the environment, reducing the final price of the product and/or increasing the profit margin, without changing the quality of the supplied object. For applications which undergo impact loads, virgin PP should be used, since the mixtures with recycled PP demonstrated a lower impact strength.

\section{ACKNOWLEDGEMENTS}

First of all, we would like to thank Professor Fabio Knewitz for his attention in teaching how to operate the universal testing machine for tensile tests. Professor Luciano Aparecido Kempski, as well as the laboratory technicians Arthur and Emerson, for the idea and assistance in the preparation of the sample holder for the execution of the notch in the specimens of the impact test. Professor Douglas Simon of the IFRS - Campus Farroupilha for providing his time for the execution of the impact tests. And, finally, thank the company Cavaletti S.A., for supplying the samples for the experimental tests.

\section{REFERENCES}

[1] Hopewell, J., Dvorak, R., \& Kosior, E. Plastics recycling: challenges and opportunities. Philosophical Transactions of the Royal Society B: Biological Sciences, 364, 2115-2126, 2009. doi:10.1098/rstb.2008.0311.

[2] Espíndola, L. C. Reciclagem de Plásticos Pós-Consumo Misturados não Reaproveitados pelos Centros de Triagem de Porto Alegre. Universidade Federal do Rio Grande do Sul, Porto Alegre, 2004.

[3] Mantia, F. Handbook of Plastics Recycling. Shawburry, UK: Rapra Technology Limited, 2002.

[4] Alcântara, R. L., Carvalho, L. H., \& Ramos, S. M. Propriedades Mecânicas de Resíduos Plásticos Urbanos da Região Nordeste. I - Influência das Condições de Processamento. Polímeros: Ciência e Tecnologia, 5(3), 42-47, 1995.

[5] Shent, H., Pugh, R. J., \& Forssberg, E. A review of plastics waste recycling and the flotation of plastics. Resources, Conservation and Recycling, 25(2), 85-109, 1999. doi: 10.1016/S0921-3449(98)00017-2.

[6] Petry, A. Mercado Brasileiro de Polipropileno com Ênfase no Setor Automobilístico. Universidade Federal do Rio Grande do Sul, Porto Alegre, 2011.

[7] Parente, R. A. Elementos Estruturais de Plástico Reciclado. Universidade de São Paulo, São Carlos, 2006. 
[8] Fernandes, B. L., Domingues, A. J. Caracterização Mecânica de Polipropileno Reciclado para a Indústria Automotiva. Polímeros: Ciência e Tecnologia, 15(2), 85-87, 2007. doi: 10.1590/S0104-14282007000200005.

[9] Raj, M., Patel, H., Raj, L., \& Patel, N. Studies on mechanical properties of recycled polypropylene blended with virgin polypropylene. International Journal of Science Inventions Today, 2(3), 194-203, 2013.

[10] Ashton, E. G., Kindlein, J. W., Cândido, L. H., Demori, R., Robinson, L. C., \& Mauler, R. Design, materiais e sustentabilidade: micronização de produto multi-material visando sua reciclagem. Da pesquisa, 10(14), 138-155, 2015. doi: 10.5965/1808312910142015145.
[11] Aurrekoetxea, J., Sarrionandia M. A., Urrutibeascoa I., \& Maspoch, M. L. Effects of recycling on the microstructure and the mechanical properties of isotactic polypropylene. Journal of Materials Science, 36(11), 2607-2613, 2001. doi: 10.1023/A:1017983907260.

[12] Strapasson, R. Valorização do polipropileno através de sua mistura e reciclagem. Universidade Federal do Paraná, Curitiba, 2004.

[13] Bahlouli, N., Pessey, D., Raveyre, C., Guillet, J., Ahzi, S., Dahoun, A., \& Hiver, J. M. Recycling effects on the rheological and thermomechanical properties of polypropylene-based composites. Materials and Design, 33(1), 451-458, 2012. doi: 10.1016/j.matdes.2011.04.049. 